МИЛКА В. НИКОЛИЋ

Универзитет у Крагујевцу

Филолошко-уметнички факултет
Оригинални научни рад

Примљен: 19.10.2021.

Прихваћен: 22.11.2021.

\title{
СРЕДЬОШКОЛСКА НАСТАВА СИНТАКСЕ: УСМЕРЕНОСТ НА ИСХОДЕ И НОВЕ СТУДИЈЕ ПИСМЕНОСТИ
}

\begin{abstract}
У овом раду се компетенцијски приступ настави и учењу синтаксе сагледава из перспективе Нових студија писмености, које указују да приликом унапређивања образовања треба изаћи из оквира издвојених вештина. Циљ рада јесте: (1) да се испита потенцијална улога синтаксичких компетенција у развијању одређених видова писмености у средњошколском образовању; (2) да се предложи методички концепт за наставу Српског језика и књижевности којим се уз примену синтаксичких знања и вештина доприноси развоју вишеструке писмености. Испитивање је спроведено на корпусу образовних стандарда и наставних програма. Анализа је показала: (1) да стицање синтаксичких знања и вештина доприноси развијању читалачке и функционалне писмености; (2) да корелативни и проблемски приступ наставним садржајима омогућавају наставнику да подстакне ученике на примену синтаксичких компетенција у рецепцији и продукцији текстова. Методички концепт за имплементирање синтаксичких компетенција у развој вишеструке писмености заснива се на следећим принципима: (1) контекстуализација наставних садржаја; (2) рефлексија о употреби синтаксичких јединица; (3) корелативни приступ наставним садржајима.
\end{abstract}

Кључне речи: настава синтаксе српског језика, усмереност наставе на исходе, Нове студије писмености, синтаксичке компетенције, читалачка писменост, функционална писменост, средњошколско образовање.

\section{1. Увод}

Синтакса је најзаступљенија граматичка дисциплина у програмима наставе и учења српског језика, а уз морфологију се сматра најкомплекснијим подручјем језичког образовања у основној и средњој школи (Петровачки 2004: 50). Појава нових наставних програма, усмерених на исходе учења, подстакла је научнике и

*milkanik75@gmail.com 
наставнике на преиспитивање конкретних програмских решења, као и на преиспитивање образовног концепта у целини:

Какви се данас захтеви постављају пред образовање? [...] Да ли је данашња визија образовања намењена развоју мислећег појединца или развијању стратегија за стицање компетенција, вештинама које омогућавају развој тржишта и капитала? Другачије речено, да ли се образовање трансформисало у употребљиви и мерљиви производ? Иако то свакако чини важан аспект функционисања и развоја једног друштва, треба ли да буде његов основни циљ? (Опачић/Зељић 2020: 9).

У овом раду покушаћемо да компетенцијски приступ настави и учењу синтаксе сагледамо из перспективе Нових студија писмености, које указују да приликом унапређивања образовања треба изаћи из оквира издвојених вештина практикованих искључиво у школским ситуацијама. Термин нова писменост подразумева постојање различитих врста писмености (језичка, научна, информациона, информатичка, медијска и др.), које се надограђују и након институционализованог образовања, а које су појединцу потребне за лични и професионални развој, као и за партиципацију у социокултурном окружењу. Стицање компетенција се може повезати са изграђивањем тзв. вишеструке писмености, на пример, језичке компетенције учествују у развијању језичке писмености, информатичке компетенције у развијању информатичке писмености итд. (уп. Јурић 2013).

Стицање синтаксичких знања и вештина припада језичком образовању и доприноси изграђивању језичке писмености. Циљ овог рада јесте: (1) да се испита потенцијална улога синтаксичких компетенција у развијању одређених видова писмености у средњошколском образовању; (2) да се предложи методички концепт за наставу Српског језика и књижевности којим се уз примену синтаксичких знања и вештина доприноси развоју вишеструке писмености. ${ }^{1}$

Испитивање се спроводи на корпусу који обихвата образовне стандарде за крај обавезног и крај средњег образовања, као и гимназијске наставне програме за предмет Српски језик и књижевности. Очекивано је да синтаксичка знања и вештине имају значајну улогу у развијању читалачке и функиионалне писмености. Исто тако, може се очекивати да ће корелативни и проблемски приступ наставним садржајима подстаћи ученике да сходно контексту примењују синтаксичке компетенције у рецепцији и продукцији текстова.

${ }^{1} \mathrm{У}$ центру наше пажње биће опште средње образовање, а за другу прилику остављамо разматрање стручног средњег образовања. У средњим стручним школама може се успостављати међупредметна корелација Српског језика и књижевности са стручним предметима и тиме допринети развоју професоналних компетенција код ученика. 


\section{2. Приступ проблему}

\section{1. Усмереност на компетенције и Нове студије писмености}

Савремени образовни процес оријентише се према исходима учења - сматра се да је такав концепт користан и за наставника и за ученика: ${ }^{2}$

(a) исходи помажу ученицима да схвате шта је потребно да науче, пружају им ослонац за организацију рада и управљање активностима, омогућавају им да самостално прате и оцењују своје напредовање, подстичу их да формирају и унапређују стратегије учења (в. Микановић 2014: 85-86);

(б) исходи помажу наставницима при избору „наставих стратегија, метода и поступака, чиме се олакшава дидактичко-методичко креирање процеса поучавања и учења", затим, представљају ослонац за селекцију и структурирање наставних садржаја, омогућавају прецизније праћење и вредновање ученичких постигнућа (в. Микановић 2014: 85-86).

Компетенцијски приступ образовању може бити критикован са више аспеката, посебно са аспекта наглашеног „прагматичног, функционалног и економског приступа образовању” (Ћатић 2012: 185). Сматрамо да треба искористити потенцијал усмерености на исходе, а уједно процес наставе и учења заснивати на конструктивистичком приступу уз уважавање социокултурног окружења у коме се образовање одвија. Један од начина да се то постигне јесте оријентација према концепту Нових студија писмености.

Да би концепт Нових студија писмености могао сврсисходно да се примени у образовању, пожељно је да се уваже следећи принципи:

(a) писменост се не може научити „из лекција” нити се може свести на „скуп пробраних компетенција за нови век” (Митровић 2010: 169);

(б) вештине не треба искључити из образовања, него их треба посматрати као чиниоце развоја - „на њихово место треба да дође брига о развоју, а вештине имају смисла као елементи вођеног развоја” (Митровић 2010: 169);

(в) „садржај писмености индивидуе” - једним делом је личне природе јер „[се] тиче различитих аспеката идентитета и интегритета”, а другим делом је локално-социјалне природе јер „,[се] тиче садржаја образовања и начина како индивидуа на основу њега и сопствених искустава конституише сопствено место у окружењу и култури у целини” (Митровић 2010: 171).

Значајно је да се укаже да писменост представља контекстуално осетљив феномен. Стога, имплементацију синтаксичких компетенција у развој вишеструке писмености треба спроводити кроз контекстуализоване наставне садржаје (уп. Вељковић Станковић 2013: 38-73).

\footnotetext{
${ }^{2}$ „Исходи се увек дефинишу као минимални прагови компетенција, које би просечан или сваки ученик морао постићи да би завршио одређени програм” (Бранковић 2009: 85).
} 


\section{2. Општи методички концепт савремене} наставе синтаксе

Уз ослањање на унапређену таксономију образовних циљева Бењамина Блума и на новије когнитивне теорије, за наставу синтаксе су постављени следећи општи задаци: (1) стицање знања о системима флексије и синтаксичких јединица; (2) разумевање синтаксичких категорија и законитости; (3) уочавање значењских веза у реченици; (4) примена знања при анализи конкретних синтаксичких јединица; (5) примена правописних правила у вези са синтаксом; (6) развијање аналитичког и синтетичког мишљења; (7) стваралачка примена синтаксичког знања у усменом и писаном изражавању; (8) тумачење текста са синтаксичко-стилистичког аспекта (в. Петровачки 2004: 61).

Погодном теоријском основом за обраду синтаксичких програмских садржаја сматра се интегрални приступ, који упућује ученике да повезују граматички систем и речник (Петровачки 2008: 41-42). За наставу се препоручује: (1) да се примењује комуникативно-граматичка анализа реченице, што подразумева „да реченицу треба тумачити као морфосинтаксичку ниску у којој се свакој морфосинтаксичкој речи [...] одређује врста и подврста, класификационе категорије, граматички облик, морфолошке категорије и лексема са реализованим конкретним значењем у тој реченици” (Петровачки 2008: 41) ${ }^{3}$ (2) да се у анализи реченице користе табеле и дијаграми, чиме се ученици усмеравају на активно стицање знања (Петровачки 2008: 70).

Настава синтаксе захтева примену вишекритеријалне анализе, што ову граматичку област чини веома сложеном и за наставну обраду:

Сваком синтаксичком појму у анализи треба сагледати најмање три аспекта: облик, значење и функцију. Наравно, у интегралном и комуникативном приступу треба обратити пажњу и на конкретно текстуално значење синтаксичке јединице реализивано у исказу. Стога су синтаксичке анализе помало и проблемске ситуације које треба постепено решавати. Неопходно је обратити пажњу истовремено на више критеријума које треба увидети, разумети и повезати, те је важно да се ученицима конкретна синтаксичка јединица или проблем што очигледније представе (Петровачки/Штасни 2008: 78-79).

У наставку излагања размотрићемо потенцијалну улогу синтаксичких знања и вештина у изграђивању одређених видова писмености, а затим ћемо предложити методички концепт којим се синтаксичке компетенције могу укључити у развој вишеструке писмености.

3 За примену комуникативно-граматичког приступа у настави синтаксе неопходно је познавати појмовно-терминолошки систем овог приступа, као и његов теоријско-методолошки концепт (в. Кликовац 2017). 


\section{3. Резултати анализе}

\section{1. Улога синтаксичких знања и вештина у развијању вишеструке писмености}

Улогу синтаксичких знања и вештина у изграђивању вишеструке писмености можемо пратити на рецептивном и продуктивном плану, што нам омогућава да различите видове писмености у којима учествују синтаксичке компетенције објединимо посматрајући их кроз визуру читања (рецепција) и писања (продукција). Читање и писање у савременом образовању превазилазе оквире базичних вештина алфанумеричке писмености и укључују се у развијање двају видова писмености неопходних за лични, професионални и социокултурни идентитет и интегритет појединца:

(a) читалачка писменост - „разумевање, коришћење и размишљање о писаним текстовима да би се постигли лични циљеви, развила знања и потенцијали и да би се партиципирало у друштву” (Павловић Бабић/Бауцал 2009: 6).

(a) функиионлана писменост - „овладавање језичким знањем и способностима да се различите информације - тачно, складно и примерено комуникативној сврси - језички уобличе у текстовне форме” (Јовановић 2010: 51).

Образовним стандардима за крај обавезног образовања одређена су постигнућа за разумевање прочитаног и за писано изражавање, која ћемо посматрати као рецептивне и продуктивне вештине:

(a) рецептивне вештине - разликовање уметничких и неуметничких текстова, разликовање сврхе текста (експозиција, дескрипција, нарација, аргументација, пропаганда), познавање врста неуметничког текста (технички опис, техничко приповедање и др.), познавање функционалних стилова;

(б) продуктивне вештине - прилагођавање језичког израза медијуму (усмени, писани), теми, прилици и сл., затим, употреба одговарајућег језичког варијетета (формални, неформални), састављање текста са одређеном сврхом (експозиторни, наративни, дескриптивни, аргументативни).

Општи стандарди постигнућа за крај средњег образовања предвиђају да се ученик на средњем нивоу знања користи свим синтаксичким могућностима српског језика. Такво постигнуће подразумева памћеґе, разумевање и примену. Развој вишеструке писмености подстицаћемо активирањем виших когнитивних функција, у које, према ревидираној таксономији образовних циљева Бењамина Блума, спадају анализа, евалуащија и синтеза (уп. Андерсон/Кратвол 2001). 


\section{2. Методички концепт којим се синтаксичке компетенције укључују у развој вишеструке писменост}

Развоју вишеструке писмености погодују наставне методе које обезбеђују активно учешће ученика, аутономију у решавању проблема и задатака, као и развој процедуралних знања (уп. Јурић 2013). Корелативни и проблемски приступ наставним садржајима доприносе унапређивању генеративних и трансферних знања, што треба узети у обзир приликом подстицања ученика да синтаксичке компетенције примене у читању и разумевању различитих типова текстова, као и у усменом и писаном изражавању.

Предлажемо да се методички концепт за укључивање синтаксичких компетенција у развој вишеструке писмености успостави на следећим принципима: (1) контекстуализација наставних садржаја; (2) рефлексија о употреби синтаксичких јединица; (3) корелативни приступ наставним садржајима.

Посебно је значајна контекстуализација наставних садржаја јер се комуникативно-граматичка анализа увежбава на појединачним реченицама (издвојеним из текста и ванјезичког контекста). Након обраде синтаксичких садржаја треба реализовати активности осмишљене на текстовима који припадају одређеним ванјезичким контекстима. ${ }^{4}$

Рефлексију о употреби синтаксичких јединица треба заснивати на искуствима која пружају функционална стилистика, интегрална стилистика и критичка анализа дискурса. ${ }^{5}$ Теоријска и практична сазнања ових дисциплина интегришу се у проблемска питања помоћу којих се сагледава употреба синтаксичких јединица у конкретном контексту.

Потребно је да се наставна област Језик повеже како са Кюижевношћу тако и са Језичком културом. ${ }^{6}$ Корелација наставе језика и књижевности остварује се применом приступа интегралне стилистике, који обједињује књижевну и лингвистичку стилистику (уп. Ковачевић 2018). Међутим, целокупна настава језика не може се остваривати искључиво на примерима из књижевности, што се односи на (под)области „функционалне стилистике, језичке културе (нормативистична коректност изговореног или написаног текста [...]) или функционалне писмености (стилска и жанровска коректност, односно нормативност текста)", у којима се мења лингвистички фокус са језика на текст (Милановић 2021: 40). У тим (под)областима неопходно је успостављати унутарпредметну корелацију наставе језика и језичке културе.

${ }^{4}$ Ове активности треба реализовати у трећем и четвртом разреду гимназије, на часовима намењеним за утврђивање језичких знања или на часовима језичке културе.

${ }^{5}$ У методичкој литератури предлаже се примена интердисциплинарног приступа у настави језичке културе (в. Капларевић 2017).

${ }^{6}$ У методичкој литератури се указује на значај корелативног приступа у новим програмима наставе и учења књижевности (в. Мркаљ 2020). 
У наставку излагања наводимо примере ученичких активности којима се синтаксичке компетенције укључују у развој вишеструке писмености. Примењен је предложени методички концепт. Три активности подразумевају унутарпредметну корелацију, а четврта међупредметну корелацију. ${ }^{7}$

\section{4. Примери активности којима се синтаксичке компетенције укључују у развој вишеструке писмености}

\section{1. Синтаксичке јединице кроз функционалне стилове}

Ова активност обухвата синтаксичка и функционалностилистичка знања. Ванјазички контексти у оквиру којих посматрамо употребу синтаксичких јединица јесу подручја комуникације за која се везују функционални стилови.

Како би на рецептивном плану подстакао развој писмености, наставник ће из различитих функционалних стилова припремити текстове (или одломке), у којима ће ученици разматрати један структурно-семантички тип синтаксичких јединица или један ужи део (подсистем) синтаксичког система. ${ }^{8}$

Рефлексија о употреби синтаксичких јединица односи се на сврху и начин њихове употребе у сваком стилу, а након разматрања свих функционалних стилова спроводи се систематизација знања. Систематизацијом се, уз прилагођавање гимназијском знању, обухватају кључне синтаксичке разлике између стилова (уп. Прањковић 1996). Кључне синтаксичке разлике између стилова ученицима се могу приказати преко следећих критеријума: (1) да ли доминирају глаголске или именске јединице - стилови се на основу овог критеријума деле на конкретне (разговорни, књижевноуметнички) и апстрактне (научни, административни, публицистички); ${ }^{9}$ (2) да ли у сложеној реченици доминирају везничке или невезничке конструкције - у конкретним стиловима доминирају невезничке, а у апстрактним доминирају везничке конструкције; (3) да ли у сложеној реченици доминирају субординативне или координативне конструкције - у конкретним стиловима доминирају координативне, а у апстрактним доминирају субординативне конструкције.

Развој писмености на продуктивном плану подстиче се вежбама стилског преобликовања одређеног текста из функционалног стила коме тај текст припада у друге стилове. Након извршеног преобликовања разматра се шта се догодило са датом синтаксичком јединицом (да ли је замењена другом јединицом, којом јединицом је замењена, зашто је та јединица погоднија и сл.).

\footnotetext{
${ }^{7}$ Све активности подразумевају да се осим употребе синтаксичких јединица анализира и избор лексике, дакле, неопходно је остваривати трансфер знања из лексикологије.

${ }^{8}$ Као илустрацију поменућемо употребу поредбених и начинских синтаксичких јединица у различитим функционалним стиловима (в. Николић 2014).

${ }^{9}$ Наставник се при објашњавању ове разлике може ослонити на лекцију из уџбеника за основну школу: „Да ли да се изражавамо глаголима или глаголским именицама” (в. Кликовац 2011: 127-129).
} 


\section{2. Конкретно и апстрактно/уопштено изражавање}

Како би ученици проширили функционалностилистичка знања, наставник ће у овој активности применити искуства која пружа критичка анализа дискурса (уп. Кликовац 2008: 247-265). Ванјазички контексти у оквиру којих се посматра употреба синтаксичких јединица јесу наука и администрација: (1) на примерима из научних текстова уочава се оправдана употреба апстрактног/уопштеног начина изражавања; (2) на примерима из административних текстова критички се сагледава употреба апстрактног/уопштеног начина изражавања.

Развој писмености на рецептивном плану и рефлексија о употреби синтаксичких јединица подстичу се кроз две фазе наставног рада.

У првој фази рада разматрају се текстови из науке (наставник може користити одломке из средњошколских уџбеника). Потребно је да ученици уоче синтаксичке конструкције које су тешке за разумевање. На основу синтаксичког знања којим располажу они могу уочити конструкције у којима се не исказује агенс (пасивне и обезличене конструкције). Уз помоћ наставника уочиће употребу непредикатских јединица (нпр. глаголска именица, глаголски прилог) уместо предикатских клауза. Рефлексија о употреби синтаксичких јединица подразумева да се одговори на следећа проблемска питања: (1) Зашто су претходно поменуте конструкције тешке за разумевање? (Наставник усмерава ученике да запазе да у реченици недостају подаци о вршиоцу радње, односно подаци који се исказују личним глаголским обликом); (2) Зашто се у науци употребљавају такве конструкције? (Наставник усмерава ученике да запазе да наука тежи да једном реченицом обухвати што више информација, што доводи до веће заступљености непредикатских јединица и именског начина изражавања).

У другој фази наставног рада разматрају се административни текстови (погодни су краћи текстови које институције упућују грађанима). У рефлексију о употреби синтаксичких јединица укључује се приступ критичке анализе дискурса, при чему ће наставник усмерити ученике да запазе: (1) да у комуникацији учествују институција и грађанин; (2) да та два комуникатора нису равноправна - институција има надређену, а грађанин подређену позицију; (3) да се надређена позиција институције, између осталог, препознаје у употреби синтаксичких конструкција којима се постиже апстрактно/уопштено изражавање (ове конструкције ће грађанину бити тешке за разумевање). ${ }^{10}$

Како би на продуктивном плану подстакао развој писмености, наставник ће припремити текстове у којима се јавља апстрактно/уопштено изражавање, које ће ученици трансформисати у конкретно изражавање. Стилске вежбе тог типа познате су из методичке литературе (в. Николић 1992: 614-615; Николић 2002: 115-116). Погодни су текстови из медија јер се очекује да медијски текстови буду разумљиви читаоцима/слушаоцима, што се често не остварује. Посебно су ефектни примери у којима се јавља бирократски језик. Бирократски језик

\footnotetext{
${ }^{10}$ Наставнику је у лингвистичкој литератури доступна анализа судског решења о почињеном саобраћајном прекршају, на коју се може ослонити (в. Кликовац 2008: 247-265).
} 
се одликује неоправданом употребом апстрактног/уопштеног изражавања, што говорницима служи да оставе утисак учености и стручности када говоре за медије. ${ }^{11}$

\section{3. Неутрално и сугестивно/експресивно изражавање}

Активност која се односи на проблем адекватне употребе стилски неутралног (стилски необележеног) и сугестивног/експресивног изражавања ослања се на ученичке компетенције стечене у основној школи: (1) разликовање врста текстова зависно од сврхе текста (експозиција, дескрипција, нарација, аргументација, пропаганда); (2) разликовање сугестивне нарације од техничке нарације, као и сугестивне дескрипције од техничке дескрипције. Рефлексија о употреби синтаксичких јединица подразумева да се одговори на следећа питања: (1) У којим ситуацијама се користи неутрално, а у којим сугестивно/експресивно изражавање? (2) У којим ситуацијама се сугестивно/експресивно изражавање сматра примереним, а у којим ситуацијама се сматра непримереним?

Значајно је да ученици запазе: (1) да се сугестивно/експресивно изражавање користи не само у књижевности, него и у свакодневним ситуацијама; (2) да је примерено употребљавати такво изражавање у приватном (неформалном) контексту, док је неутрално изражавање неопходно користити у формалним ситуацијама. За унапређивање писмености на рецептивном плану посебно је значајно да наставник на примерима покаже да се неутрално односно сугестивно/ експресивно изражавање постиже избором лексике, али и синтаксичким конструкцијама. Ученицима су из књижевности познати поједини језичко-стилски поступци којима настају стилски обележене синтаксичке конструкције. Реч је о поступцима премештања и изостављања реченичних и синтагматских конституената (стилске фигуре инверзија и елипса).

Унапређивање писмености на продуктивном плану постиже се стилским вежбама којима се ученици оспособљавају да говоре стилски неутрално у формалним приликама. Задатке (теме) за стилске вежбе треба конкретизовати и повазати са познатим ситуацијама из друштвеног живота.

\section{4. Превођење са страног језика на српски и обратно}

Превођење са станог језика на матерњи и обратно представља сложенији тип активности у односу на претходне јер обухвата језичку, читалачку и функционалну писменост на матерњем и страном језику. ${ }^{12}$

Поред стицања преводилачких компетенција и унапређивања претходно поменутих видова писмености на полазном и циљном језику, превођење допри-

\footnotetext{
${ }^{11}$ Наставнику је као ослонац погодан пример који показује како се елиминише бирократски језик из изјаве једног агронома емитоване на радију (в. Кликовац 2008: 11-22).

${ }^{12}$ Вежбе превођења се користе у настави српског као страног језика за унапређивање разумевања прочитаног, а погодне су и за наставу Српског [матерњег] језика и књижевности у основној и средњој школи (в. Мркаљ 2011).
} 
носи развијању лингвокултуралних компетенщија у оба језика, затим, доприноси и изграђивању културне и мултикултурне писмености, које улазе у састав вишеструке писмености (в. Митровић 2012: 154).

Наставницима српског језика се предлаже да кроз тимски рад с наставницима страног језика примењују преводилачке активности на текстовима који припадају различитим функционалним стиловима. Значајно је да осим одломака књижевних дела буду заступљени текстови (жанрови) с којима се ученици срећу у свакодневном животу (нпр. упутство за употребу уређаја, декларација на прехрамбеном производу, туристички проспект и сл.). Након што ученици преведу текст, спроводи се анализа адекватности превода и коментарисање преводилачких решења.

\section{5. Закључак}

Ако се из перспективе Нових студија писмености сагледа компетенцијски приступ настави и учењу синтаксе у средњошколском образовању, долази се до закључка да стицање синтаксичких знања и вештина доприноси развијању/ изграђивању вишеструке писмености.

Улога синтаксичких компетенција у изграђивању вишеструке писмености остварује се, условно, у два правца: (1) читалачка писменост - која се може посматрати као рецептивно оријентисана област; (2) функционална писменост - која се може посматрати као продуктивно оријентисана област.

Методички концепт за имплементирање синтаксичких компетенција у развој вишеструке писмености базира се на следећим принципима:

(1) контекстуализација наставних садржаја - након обраде синтаксичких садржаја треба реализовати активности осмишљене на текстовима који припадају одређеним ванјезичким контекстима;

(2) рефлексија о употреби синтаксичких јединица - потребно је применити теоријска и практична сазнања различитих филолошких дисциплина (функционална стилистика, интегрална стилистика, критичка анализа дискурса) при осмишљавању проблемских питања помоћу којих се сагледава употреба синтаксичких јединица у одређеном контексту;

(3) корелативни приступ наставним садржајима - повезивање наставних области односно наставних предмета доприноси унапређивању генеративних и трансферних знања, што је значајно за подстицање ученика да синтаксичке компетенције примене у читању и разумевању различитих типова текстова, као и у усменом и писаном изражавању.

Да би синтаксичке компетенције могле да се имплементирају у ученичке рецептивне и продуктивне потенцијале за развијање вишеструке писмености, потребно је довести ученике у ситуацију: (1) да самостално запажају, промишљају и коментаришу употребу синтаксичких јединица у конкретном ужем 
и ширем контексту; (2) да употребљавају одговарајуће синтаксичке јединице сходно друштвеним (ванејзичким) контекстима који су им познати.

Према схватањима која заступа концепт Нових студија писмености, појединац и након школовања (током читавог живота) унапређује различите видове писмености, помоћу којих заснива сопствени идентитет и интегритет, партиципирајући у одређеном социокултурном окружењу. Значајну улогу у том процесу има језичко образовање, посебно овладавање синтаксичким компетенцијама, захваљујући којима појединац може да разуме реченице и текстове, као и да и их формира.

\section{ИЗВОРИ}

Стандарди обавезног образовања 2010: Образовни стандарди за крај обавезног образовања за наставни предмет Српски језик, Београд: Завод за вредновање квалитета образовања и васпитања.

Стандарди средњег образовања 2015: Општи стандарди постигнућа за крај општег средњег и средњег стручног образовања и васпитања у делу општеобразовних предмета за предмет Српски језик и кюижевност, Београд: Завод за вредновање квалитета образовања и васпитања.

Програм наставе и учења 2020: Правилник о плану и програму наставе $u$ учења за гимназију, Службени гласник Републике Србије - Просветни гласник, LXIX/4, Београд.

\section{ЛИТЕРАТУРА}

Андерсон/Кратвол 2001: L. W. Anderson, D. Krathwohl, A taxonomy for learning, teaching, and assessing: a revision of Bloom's taxonomy of educational objectives, New York: Addison Wesley Longman.

Бранковић 2009: Д. Бранковић, Циљеви, компетенције и исходи васпитања и образовања, у: К. Шпијуновић (ур.), Образовање и усавршавање наставника, Ужице: Учитељски факултет, 79-88.

Вељковић Станковић 2013: Д. Вељковић Станковић, Комуникативни приcтуn у настави српског језика, Београд: Друштво за српски језик и књижевност Србије.

Јовановић 2010: Ј. Јовановић, Предметни опсег и методолошки оквир 'функционалне писмености', у: А. Вранеш, Љ. Марковић (ур.), Школска библиотека и настава језика и књижевности, Београд: Филолошки факултет, 23-54.

Јурић 2013: С. Јурић, Нова писменост - дефиниција и типологија вишеструких писмености. http://obrazovneparadigme.pbworks.com/w/page. 28. 08. 2021.

Капларевић 2017: Т. Капларевић, Интердисциплинарни приступ писменим саставима у настави језичке културе, Методички видищи, 8, Нови Сад, 115-134. 
Кликовац 2008: D. Klikovac, Jezik i moć: ogledi iz sociolingvistike, Beograd: Biblioteka XX vek.

Кликовац 2011: Д. Кликовац, Српски језик и језичка култура за 8. разред, Београд: Завод за уџбенике.

Кликовац 2017: Д. Кликовац, Како проста реченица може бити сложена (O подели реченица „по саставу”), Кьижевност и језик, LXIV/1-2, Београд, 1-24.

Ковачевић 2018: М. Ковачевић, Стилистика у настави српског језика, Къижевност и језик, LXV /1-2, Београд, 1-21.

Микановић 2014: Б. Микановић, Исходи учења и стандарди знања у основном образовању, Иновације у настави, XXVII/1, Београд, 84-93.

Милановић 2021: А. Милановић, Настава српског језика у средњим школама, у: М. Ковачевић (ур.), Статус српског језика и књижевности у образовном систему, Београд: Завод за унапређивање образовања и васпитања, 29-44.

Митровић 2010: М. Митровић, Писменост и образовање: перспективе Нових студија писмености, Београд: Филозофски факултет.

Митровић 2012: M. Mitrović, Pismenost kroz kurikulum: modeli, u: Š. Alibabić, S. Medić, B. Bodroški Spariosu (ur.), Kvalitet u obrazovanju-izazovi i perspektive, Beograd: Filozofski fakultet, 147-164.

Мркаљ 2011: 3. Мркаљ, Разумевање прочитаног, у: В. Крајишник (ур.), Српски као страни језик у теорији и пракси II, Београд: Филолошки факултет, Центар за српски као страни језик, 7-18.

Мркаљ 2020: 3. Мркаљ, Значај корелативног приступа у новим програмима наставе и учења књижевности, у: И. Чутура, М. Димитријевић (ур.), Књижевност за деиу у науции и настави, Јагодина: Факултет педагошких наука, 271-285.

Николић 1992: М. Николић, Методика наставе српског језика и књижевности, Београд: Завод за уџбенике.

Николић 2002: М. Николић, Стилске вежбе: вежбања за самосталну обуку у писменом и усменом изражавању, Београд: Просветни преглед.

Николић 2014: М. Николић, Функционалностилистички приступ средњошколској настави језика на примеру синтаксичког подсистема поредбених и начинских јединица, Липар, 54, Крагујевац, 27-42.

Опачић/Зељић 2020: 3. Опачић, Г. Зељић, Уводна реч, у: З. Опачић, Г. Зељић (ур.), Програмске (ре)форме у образовағу и васпитағу - изазови и перспективе, Београд: Учитељски факултет, 9-15.

Павловић Бабић/Бауцал 2009: Д. Павловић Бабић, А. Бауцал, Разумевање прочитаног: одређење и тестирање, Београд: Завод за вредновање квалитета образовања и васпитања, Институт за психологију.

Петровачки 2004: Љ. Петровачки, Синтакса у настави српског језика и къижевности, Нови Сад: Змај.

Петровачки 2008: Љ. Петровачки, Методичка истраживања у настави српског језика и књижевности, Нови Сад: Филозофски факултет. 
Петровачки/Штасни 2008: Љ. Петровачки, Г. Штасни Методичке апликаизје, Нови Сад: Филозофски факултет.

Прањковић 1996: I. Pranjković, Funkcionalni stilovi i sintaksa, Suvremena lingvistika, 41-42/1-2, Zagreb, 519-527.

Ћатић 2012: I. Ćatić, Kompetncije i kompetencijski pristup obrazovanju, Pedagogijska istraživanja, 9/1-2, Zagreb, 175-189.

\author{
Milka V. Nikolić
}

\title{
SECONDARY SYNTAX TEACHING: OUTCOMES ORIENTATION AND NEW LITERACY STUDIES
}

\author{
Summary
}

Syntax is the most common grammatical discipline in modern programs of teaching and learning the Serbian language, and along with morphology, it is considered the most complex area of language education in primary and secondary school. In this paper, the competency approach to teaching and learning is viewed from the perspective of New Literacy Studies, which suggest that when improving education should go beyond the framework of isolated skills practiced exclusively in school situations. The aim of this paper is: (1) to examine the potential role of syntactic competencies in the development of other forms of literacy in secondary education; (2) to propose a methodological concept for the teaching of Serbian language and literature which, with the application of syntactic knowledge and skills, contributes to the development of multiple literacy. The survey was conducted on a corpus of educational standards and curricula. The analysis showed that syntactic competencies play a significant role in the development of reading and functional literacy, as well as that a correlative and problem-based approach to teaching content can encourage students to apply syntactic knowledge and skills in the reception and production of texts. It is proposed that the methodological concept for the inclusion of syntactic competencies in the construction of multiple literacy be established on the following principles: (1) contextualization of teaching content; (2) reflection on the use of syntactic constructions; (3) correlative approach to teaching content. Bringing students into a situation to independently observe, reflect and comment on syntactic phenomena enables syntactic knowledge to become part of students' expressive potentials.

Key words: Serbian language syntax teaching, outcome-oriented teaching, New literacy studies, syntactic competences, reading literacy, functional literacy, secondary education. 